\title{
Flexural Behaviour of Timber Glass Composite Beams using Various Adhesives
}

\section{S.Revathi , M.Washim Madhar}

\begin{abstract}
This paper mainly deals with providing a clear understanding of the bonding nature of various adhesives as a structural connection in timber glass composite beams and investigates the flexural behaviour of the same. This paper depicts the clear idea of the critical factors to be considered for the application of adhesives as a structural connection in timber glass composite beams. The timber glass composite beams will be a significant alternative for the conventional beams, which are currently used in the beams in temporary structures. Apart from being a significant replacement for the conventional beams, the glass web portion permits the light to pass through it. Thus, the artificial light energy required inside the structure will be reduced. This makes the composite beams to be energy efficient structural component in the temporary structures. In this research, the flexural behaviour of the composite beams made using various adhesives such as Acrylic, Epoxy and Silicone were studied. The result shows that epoxy adhesive connection behaves much better when compared with silicone and acrylic adhesives.
\end{abstract}

Keywords - Adhesive connection, Composite beams, Flexural study of beams, Timber glass beams.

\section{INTRODUCTION}

The various detailed studies on the application of polymer adhesives as a structural connection led to opening up new possibilities in the domain of connections, especially in connection of glass structures. The role of polymer materials are not only sealing but also their role is extended to load-bearing. The application of traditional bolted joints has significant problems when they are used for connecting brittle materials like glass. Some of the problems faced during implementation of the bolted connection of brittle material include non- uniform stress distribution, drilling holes in the glass, and materials with different thermal and mechanical properties cannot be joined together. Kozlowski[1], Premov[2], Hulimka[3] initiated the new possibilities of using adhesives for the development of various hybrid structures consisting of glass and steel, timber, and several other reinforcement materials. The glued connection provides the composite action between different materials in these hybrid structures. This plays a crucial role in the connection. The combination of brittle glass and ductile material enhances the load-bearing capacity of a glass structure. At the same time, this kind of combination provides a high degree of transparency and safe failure behaviour. This kind of hybrid structures requires determination of the mechanical properties of the applied adhesive in a particular joint, and also its behaviour under

Revised Manuscript Received on December 05, 2019.

S.Revathi*, Corresponding author, Assistant Professor, Department of Civil Engineering, Mepco Schlenk Engineering College, Sivakasi - 626005 TamilNadu, India. Email ID: revathi.civil7@gmail.com

M.Washim Madhar, PG Student, Department of Civil Engineering, Mepco Schlenk Engineering College, Sivakasi - 626005, TamilNadu, India. loading, with respect to the effect of environmental conditions, the thickness of the adhesive layer, the material of the substrate, and also the duration and the rate of the load.

Adhesive bonding has its application not only in hybrid structures but also in joining structural glass generally. The adhesive generally used for fabricating the adhesive glued connections is either a stiff material like acrylic or epoxy or soft elastic material like structural silicone. In 2016, The Chanel store in the Crystal Houses in Amsterdam, Netherlands, is another interesting application. The Solid glass blocks are initially positioned and transparent high-strength glue is employed to make a transparent replica of the traditional terracotta brick façade. The adhesive bonding is still a new joining technique in the civil engineering field, and it requires further research on special applications of adhesives in buildings. Even though the application of structural silicone as a connection is already been there for many years, the problems such as poor workmanship and improper processing act as a great hindrance for the development of the adhesive as a structural connection. These problems are responsible for almost $90 \%$ of the structural failures of the glue connection that have occurred. There is a wide variety of adhesives available in the market. These adhesives have various mechanical properties and hence the selection of proper glue for a particular connection is a crucial issue. The inner cohesion of polymeric material and the adhesion to the substrate is the main reason for the strength of a glued joint. Blyberg [8] says that the cohesion and adhesion property of the glue is directly influenced by the quantity and the quality of the adhesive forces between the substrate and the glue. In the case of rigid adhesives, the thickness of the adhesive layer has a significant impact on the mechanical behaviour of the beams. Hamm [9], Kreher [10] concludes that the greater the thickness of the adhesive layer, the greater is its elasticity, which ultimately leads to reduced strength. Blyberg and Lang [11] say that the degrading effect caused by the environment on the adhesive and its cohesive forces is the major considerable degrading factor in case of adhesive joints which consequently reduces the ultimate strength.

\section{LITERATURE STUDY}

Research on the composite I-beams with timber flange and glass web has been initiated in the early $21 \mathrm{st}$ century. One of the noteworthy research papers is produced by Hamm [14]. He performed experiments on eight beams with timber strips bonded to glass web. The cross-section of the composite beam is shown in figure 1. The beams taken for study have a length of $4000 \mathrm{~mm}$ and a height of $250 \mathrm{~mm}$. The cross-section of the timber strips ranging from $30 \mathrm{~mm} \times 50 \mathrm{~mm}$ to $60 \mathrm{~mm} \times 50 \mathrm{~mm}$. The float glass of 10 mm thickness was used as the web and the adhesive used for bonding was polyurethane adhesive. 
When the experiment such as flexural test was carried out by four-point bending, uniform distribution of cracking in the glass was observed. The load-bearing capacity also called as post- breakage capacity, was observed to be double relative to the load which is the reason for the formation of the cracks shows the indication of early failure. It is a very advantageous property observed in the composite timber-glass I-beams. In addition to that, Hamm [9] also included the influence of temperature (from $-30^{\circ} \mathrm{C}$ to $+70^{\circ} \mathrm{C}$ ) and moisture on the bonding of adhesives.

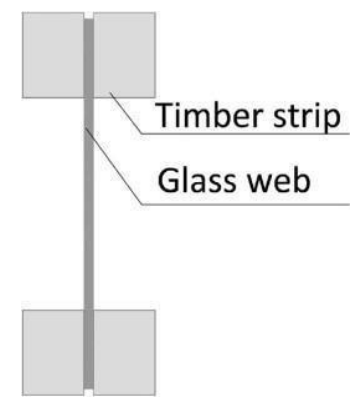

Fig.1 : Cross Section of Timber Glass composite beam

Kreher [10] performed similar investigations in the composite I beam. In his study, the glass web with a width of $4 \mathrm{~mm}$ to $6 \mathrm{~mm}$ is used. He also used various types of glass such as float glass, fully tempered glass and heat-strengthened glass. The four-point bending test was performed under quasi-static load. The study has concluded that heat-strengthened glass and fully tempered glass are not suitable for the application in the timber glass composite beams. This is mainly due to the fact that these glasses fail due to rupture and there will be no prior indication of failure. Cruz and Pequeno [16] conducted several experiments and proved that the crack distribution in the glass web is more uniform for stiffer glued bonds (polymer adhesives). They also add that there will be only smooth discontinuities on the load-displacement curve, in case of stiff glued joints. Blyberg and Serrano [11-12] investigated different types of timber flanges. The timber flanges were made with grooves, and the glass (float glass) web was placed in it and bonded. They made 7 beams and the results of those beams conclude that there is a $30 \%$ in the stiffness of the timber-glass composite beam when compared with the beam of the same dimensions but made only of timber. Kozłowski and Hulimka [13-15] studied the capacity of composite timber glass I- beams. The timber-glass I-beams were subjected to loads higher than those causing cracks. Twelve beams were taken for their study. They used three different adhesives such as acrylate adhesive, epoxy resin and structural silicone. Their investigation concluded that the beams with webs made with heat-strengthened glass have failed in a brittle manner. The first crack in glass web caused rupture failure of the whole beam.

\section{MATERIALS}

\section{A. Timber}

Timber is a natural material, the structure, properties and the characteristics of which are more complex as concrete and steel as the properties vary in different directions. The size of timber used for this research was 1000 x $200 \times 60 \mathrm{~mm}$. The groove width was provided at the centre of timber which gives stability to the web section. The size of the groove width was $21.5 \times 15 \mathrm{~mm}$.

\section{B. Glass}

The glass used for the composite timber glass I beam in this research was float glass which takes the higher load and it doesn't fail suddenly. The size of float glass used here was $1000 \times 12 \times 200 \mathrm{~mm}$. The properties of the glass were given in table I.

Table - I: Properties of glass

\begin{tabular}{|c|c|c|c|c|c|}
\hline Material & $\begin{array}{c}\text { Compressive } \\
\text { Strength }\end{array}$ & $\begin{array}{c}\text { Poisson's } \\
\text { ratio }\end{array}$ & $\begin{array}{c}\text { Shear } \\
\text { modulus }\end{array}$ & $\begin{array}{c}\text { Tensile } \\
\text { strength }\end{array}$ & $\begin{array}{c}\text { Young's } \\
\text { modulus }\end{array}$ \\
\hline $\begin{array}{c}\text { Float } \\
\text { glass }\end{array}$ & $387 \mathrm{MPa}$ & 0.25 & $34.2 \mathrm{GPa}$ & $38.7 \mathrm{MPa}$ & $83.6 \mathrm{GPa}$ \\
\hline
\end{tabular}

\section{Adhesives}

Kozlowski[1] says that the investigation of connections by using adhesives leads on from the past researches carried out on composite steel-glass beams. The adhesive glue in the connection provides the required strength and stiffness to ensure the interaction of the joining parts. However, the glue layer should be flexible and stiff enough to bear the stresses due to thermal expansions of connection materials. This is done in order to avoid the localized stress concentrations as these stresses are undesirable for polymeric materials and also for brittle glass. In this research, three types of adhesives were used. They are Acrylic, Silicone and Epoxy adhesives. These adhesives were used here for connecting the two composite materials. The adhesive was applied in between the timber and glass with the help of groove width for bonding. The properties of the three adhesives were given in table II.

Table - II: Properties of adhesives

\begin{tabular}{|c|c|c|c|c|}
\hline & $\begin{array}{c}\text { Table - II: } \\
\text { Type of } \\
\text { adhesive } \\
\text { value of } \\
\text { ultimate } \\
\text { tensile } \\
\text { strength }\end{array}$ & $\begin{array}{c}\text { Average } \\
\text { value of } \\
\text { yield } \\
\text { tensile } \\
\text { strength }\end{array}$ & $\begin{array}{c}\text { Average } \\
\text { value of } \\
\text { shear } \\
\text { strength }\end{array}$ & $\begin{array}{c}\text { Average } \\
\text { value of } \\
\text { adhesive } \\
\text { Bond } \\
\text { strength } \\
\text { value }\end{array}$ \\
\hline Acrylic & $1.61 \mathrm{GPa}$ & - & $16.9 \mathrm{MPa}$ & $12.4 \mathrm{MPa}$ \\
\hline Silicone & $6.48 \mathrm{MPa}$ & $1.22 \mathrm{MPa}$ & $0.658 \mathrm{MPa}$ & $1.18 \mathrm{MPa}$ \\
\hline Epoxy & $46.1 \mathrm{MPa}$ & $14.8 \mathrm{MPa}$ & $16.9 \mathrm{MPa}$ & $16.8 \mathrm{MPa}$ \\
\hline
\end{tabular}

\section{METHODOLOGY}

\section{A. Experimental Test Setup}

The composite I beam was placed on the UTM by fixing the support at a distance of $50 \mathrm{~mm}$ on both sides. Two rollers were placed on the specimen at a distance of $L / 3$ from the support on the top of I beam which act as two-point loads, above that the rectangular section was placed on it. The LVDT was placed on the specimen at both ends of the support. One LVDT was placed at the right top corner of the specimen. Another LVDT was placed at the left bottom

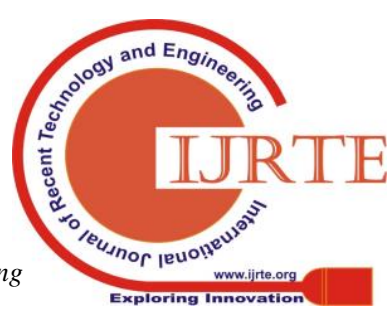


corner of the specimen. Both ends of the LVDT were connected to the Displacement Indicator. The load was applied on the specimen at regular intervals. The ultimate load of the specimen was noted.

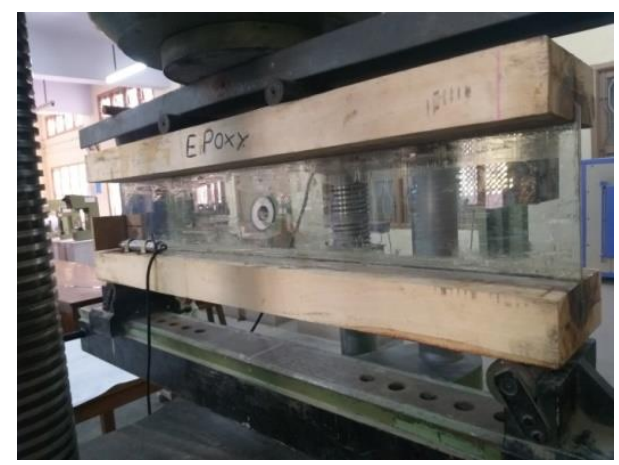

Fig. 2 : Experimental test setup

\section{B. Bending}

Three specimens were made for each type of adhesive and these were placed in position in such a way that it behaves as a simply supported beam. The beam was subjected to flexural loading of $1 \mathrm{~N} / \mathrm{mm}^{2}$ per second. Two point loading was given to the beam in order to study the pure bending effect. The load at which the crack forms is called first crack load and the load at which the specimen fails is called as the ultimate load.

\section{Shear}

The shear calculated by measuring the slip during the flexural testing of the specimen. A $3^{\text {rd }}$ dimensionally directed wood element was placed and its movement during the loading was calculated as slip by using the LVDT. The slip was calculated on both top and bottom sides of the beam.

\section{Analytical Study in ANSYS}

The beam was modeled in ANSYS workbench. The flange was given the properties of the wood and the web was given the properties of the glass. The contact region was used to define the contact behaviour on the top flange and web section. The contact region 1 was used to define the contact behaviour on the bottom flange and web section. For these two contact region, the fracture has to be defined in modelling. In fracture, contact debonding was defined for each contact region. The method used for contact debonding was Cohesive Zone Modelling (CZM). In this section, adhesive was defined in the material dialog box for each specimen. Pure penalty contact formulation was used to define the adhesive material. The adhesive material was defined using the material properties. The composite I beam was meshed using SOLID187 element. TARGE 170 and CONTAC 174 were the meshing element used in contact region for bonding. The slip and deflection of the beams with various adhesives were studied by implementing the varying properties of the adhesive layer. The deflection and slip was studied by applying the ultimate load obtained from the experimental study and the parameters such as deflection and slip were studied in ANSYS.

\section{RESULTS AND DISCUSSIONS}

The various tests were conducted on the composite timber glass composite beams and the results were noted. The results observed are discussed below.

\section{A. Bending}

The beam subjected to flexural loading of $1 \mathrm{~N} / \mathrm{mm}^{2}$ shows the following results. The shear and flexural crack of the specimens are shown in figure 3,4,5. In acrylic and silicone adhesive beams, shear crack starts from the bottom of glass at the initial crack load. In epoxy adhesive beams, flexural crack starts at the middle of glass at the initial crack load.

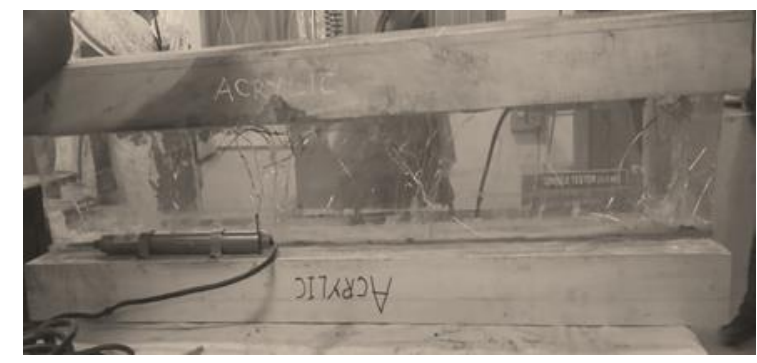

Fig.3 : Crack propagation in Acrylic adhesive specimen

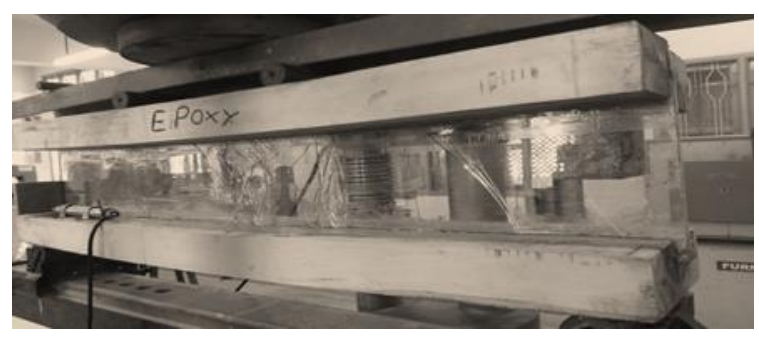

Fig.4 : Crack propagation in Epoxy adhesive specimen

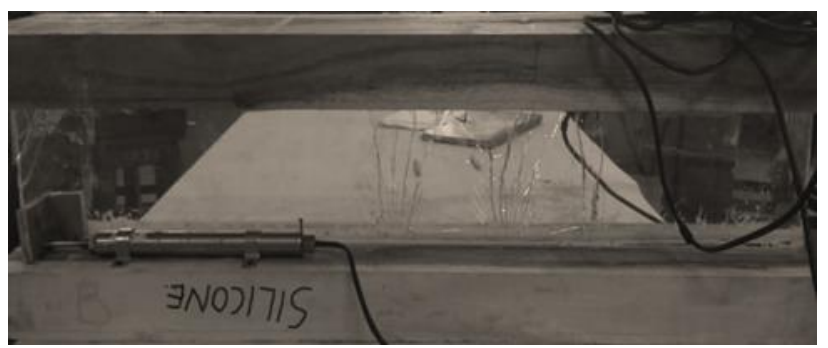

Fig.5 : Crack propagation in Silicone adhesive specimen

The load versus displacement curve obtained by the average values of three specimen are shown in figure $6,7,8$.

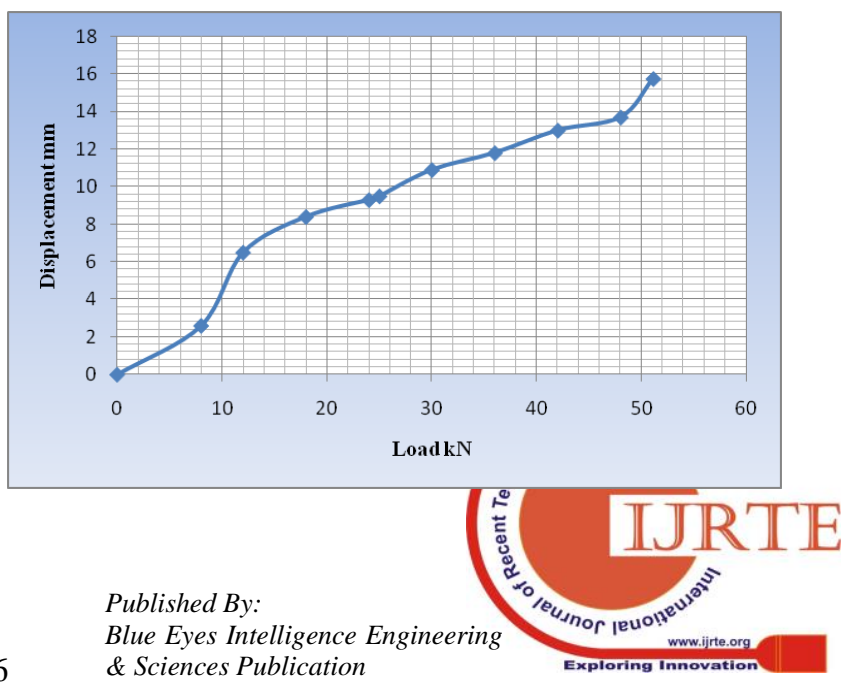


Fig.6 : Load vs Displacement curve - Acrylic adhesive

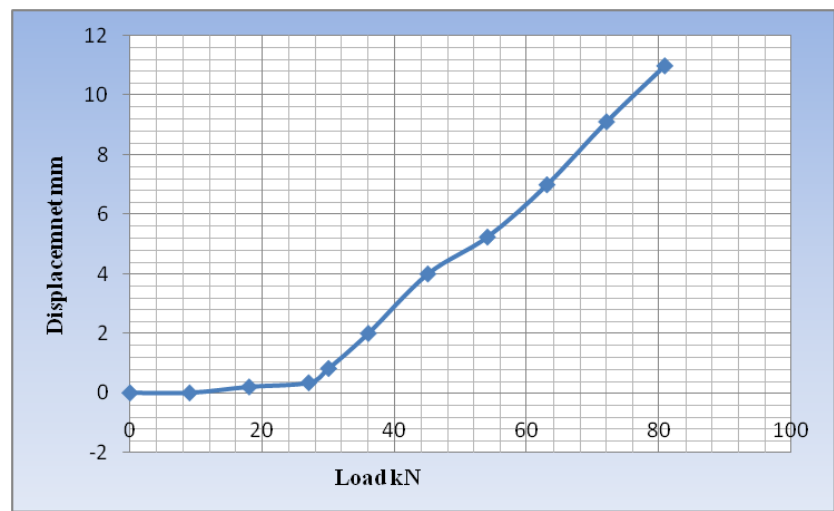

Fig.7 : Load vs Displacement curve - Epoxy adhesive

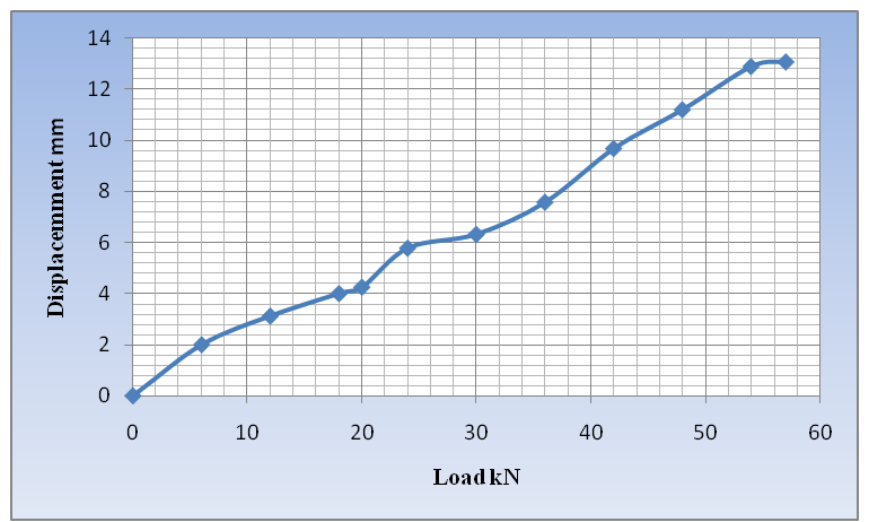

Fig.8 : Load vs Displacement curve - Silicone adhesive

From the load displacement curve, it is clear that acrylic and silicone adhesive beams undergoes slip from the application of load itself but epoxy adhesive beams undergoes slip after some time and the slip value is minimum compared to other two adhesive beams. The yield load and ultimate load were observed from the experiment and tabulated in table III.

Table - III: Results of flexural test

\begin{tabular}{|c|c|c|c|c|}
\hline $\begin{array}{c}\text { Adhesive } \\
\text { type }\end{array}$ & $\begin{array}{c}\text { Initial } \\
\text { crack } \\
\text { load, } \mathbf{k N}\end{array}$ & $\begin{array}{c}\text { Ultimate } \\
\text { load, } \\
\text { kN }\end{array}$ & $\begin{array}{c}\text { Type of } \\
\text { initial } \\
\text { crack }\end{array}$ & $\begin{array}{c}\text { Deflection, } \\
\mathbf{m m}\end{array}$ \\
\hline Acrylic & 25 & 51.10 & Shear crack & 15.75 \\
\hline Epoxy & 30 & 80.80 & $\begin{array}{c}\text { Flexural } \\
\text { crack }\end{array}$ & 11 \\
\hline Silicone & 20 & 57.5 & Shear crack & 13.07 \\
\hline
\end{tabular}

From table III, it is clear that beams with epoxy have high load bearing capacity when compared to beams with silicone and acrylic adhesives. It was also observed that the deflection was minimum in specimens with epoxy adhesive. The specimens with Silicone and acrylic adhesive formed its first crack due to shear whereas the first crack in specimens with epoxy was a flexure crack.

\section{B. Shear}

The shear was calculated to find the slip of the composite timber glass beam during loading. The results regarding slip obtained during the test are shown in table IV.

Table - IV : Results of slip measured during test

\begin{tabular}{|c|c|c|}
\hline Adhesive type & Top $\quad$ Slip, mm & Bottom slip, $\mathbf{m m}$ \\
\hline Acrylic & -0.8 & -0.91 \\
\hline Epoxy & -0.38 & -0.56 \\
\hline Silicone & 0.45 & -0.84 \\
\hline
\end{tabular}

From table IV, it is clear that the specimen with acrylic adhesive was subjected to high chances of slip. The epoxy adhesive incorporated beams shows better resistance against shear failure.

\section{Analytical Study}

The analytical study was done for composite timber glass beams and the deflection and slip was found out. The following figures show the output obtained from ANSYS Workbench. The slip of composite beam using various adhesives are shown in figures 9,11,13. The deflection of composite beam are shown in figures 10,12,14.
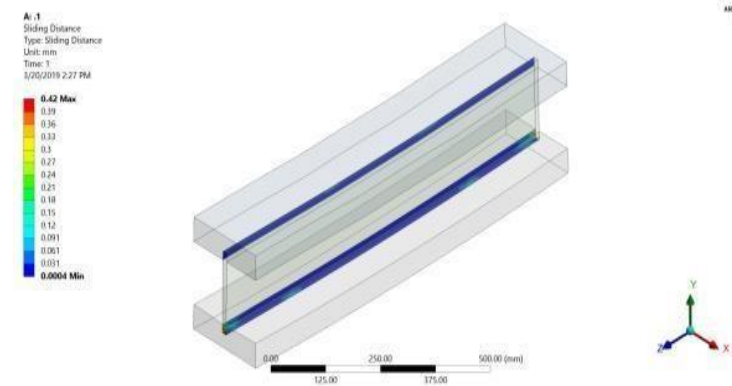

Fig.9 : Slip of composite beam with silicone adhesive
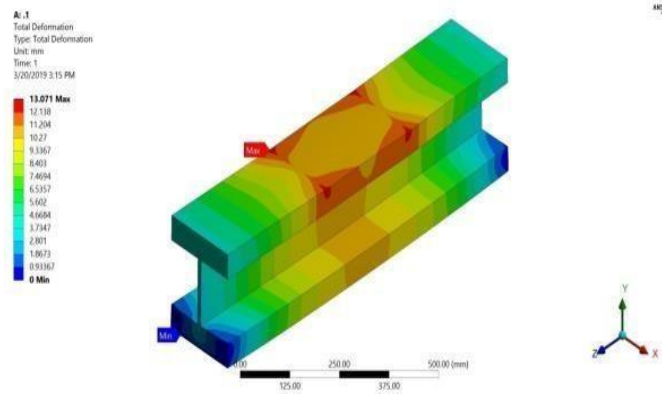

Fig.10 : Deflection of composite beam with silicone adhesive
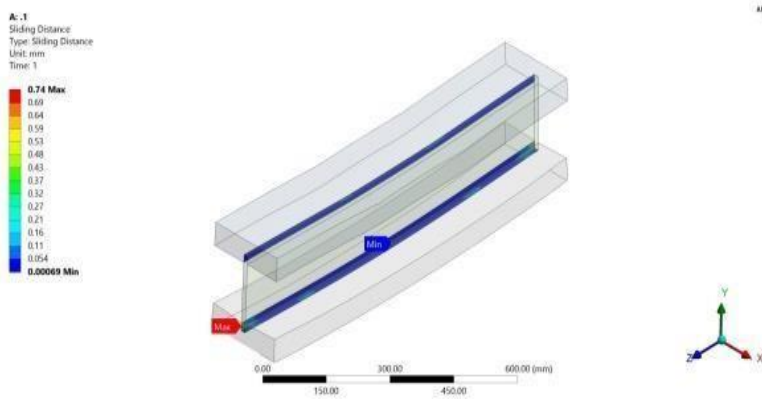

Fig.11 : Slip of composite beam with acrylic adhesive

Published By:

Blue Eyes Intelligence Engineering 


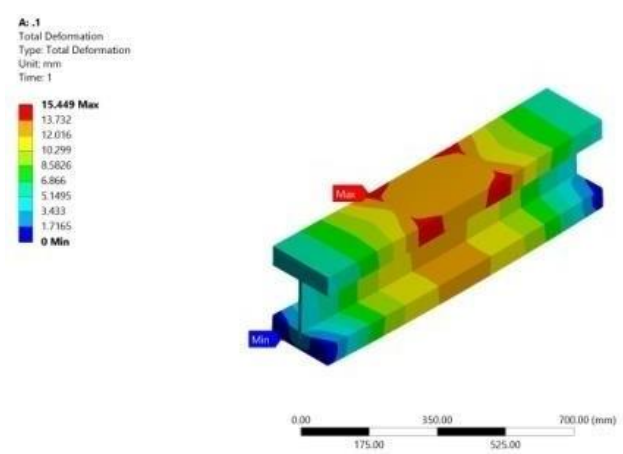

Fig.12 : Deflection of composite beam with acrylic adhesive
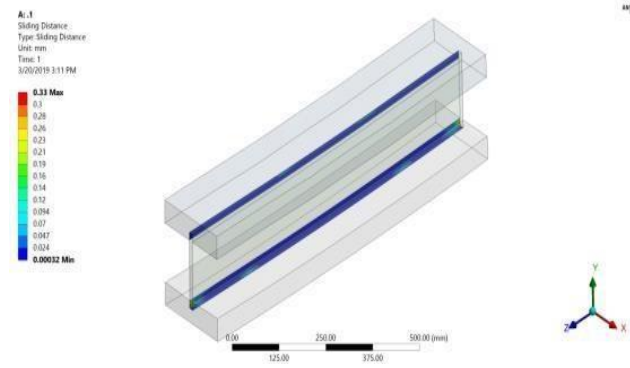

Fig.13 : Slip of composite beam with epoxy adhesive
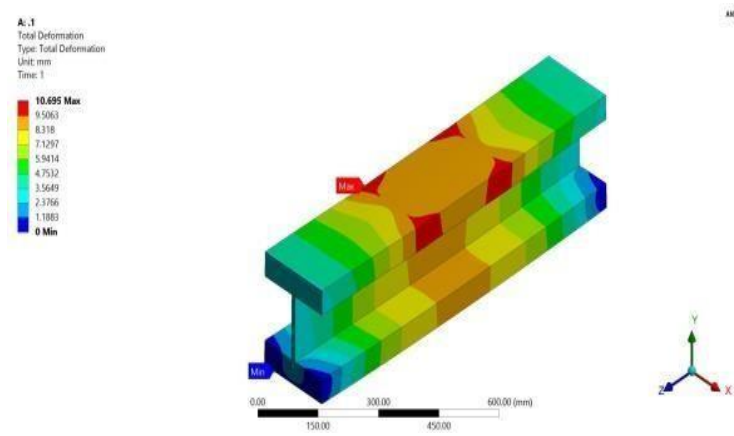

Fig. 14 : Deflection of composite beam with epoxy adhesive

The results obtained from ANSYS analytical study is depicted in table $\mathrm{V}$ as follows.

Table -V: Results of analytical study

\begin{tabular}{|c|c|c|}
\hline Adhesive Type & Maximum Slip, mm & $\begin{array}{c}\text { Maximum } \\
\text { Deflection, } \mathbf{~ m m}\end{array}$ \\
\hline Acrylic & 0.74 & 15.449 \\
\hline Epoxy & 0.33 & 10.695 \\
\hline Silicone & 0.420 & 13.071 \\
\hline
\end{tabular}

From table V, it is clear that the composite timber glass beams with epoxy adhesive have very less deflection as well as slip when compared with other adhesive types.

\section{Comparison of Analytical and Experimental Study}

\section{Deflection}

The deflection obtained from both analytical and experimental study was compared and shown in figure 15 .

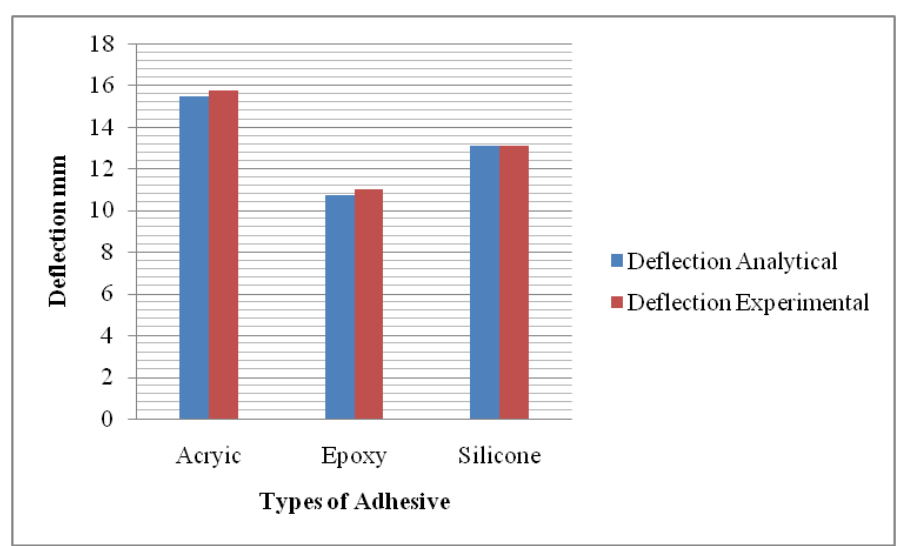

Fig.15 : Analytical and experimental results of Deflection

From the figure 15, it is clear that the experimental and analytical results were approximately same that the epoxy adhesive has very less deflection and acrylic adhesive is subjected to high deflection.

\section{Slip}

The experimental and analytical results of slip values were made into a graph for a better comparison of results which is shown in figure 16. From the figure, it is clear that the experimental results and analytical results were in accordance with each other. It was also observed that the slip occurred to a maximum when using acrylic adhesive and was minimum when using epoxy adhesive.

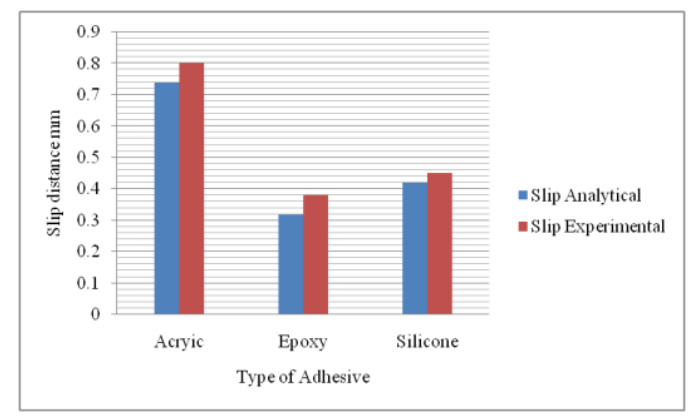

Fig.16 : Analytical and experimental results of Slip

\section{CONCLUSION}

The beams with epoxy adhesive have high ultimate flexural strength of $80.8 \mathrm{kN}$ while the beams with acrylic and silicone adhesives had low flexural strength. The failure of epoxy beams was due to flexure whereas the other adhesive incorporated beams failed by shear. The beams with acrylic adhesive were found to have more slip when compared with other beams which shows poor shear behaviour due to high slip. The deflection was found to less in beams with acrylic adhesive. The hardening time of Silicone adhesive took much time compared to Acrylic and Epoxy adhesive. The analytical study also shows that the deflection and slip were less in beams with epoxy adhesive.

Thus, this research concludes that the composite timber

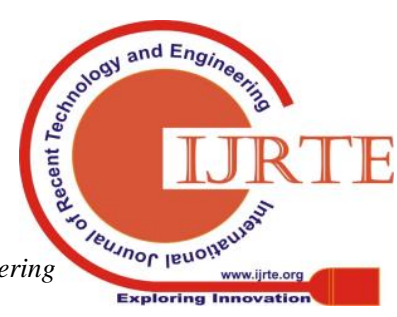


glass beams with epoxy adhesive behaves well when compared to beams with acrylic and silicone adhesives.

\section{REFERENCES}

1. M. Kozłowski, E. Serrano, B. Enquist, Experimental Investigation on Timber-Glass Composite I-Beams, Taylor \& Francis Group, London,2014.

2. Ber B, Premrov M, Strukelj A, Kuhta M. Experimental investigation of timber-glass composite wall panels, Construction Building Materials 2014;66:235-46.

3. M. Kozłowski, J. Hulimka, Load-bearing capacity of hybrid timber-glass beams, Architecture Civil Engineering Environment Journal (2014)61-70.

4. M. Premrov, M. Zlatinek, A. Strukelj, Experimental analysis of load-bearing timber-glass I-beam, Construction Unique Building Structures (2014)11-20.

5. J. Hulimka, M. Kozłowski, Mechanism of Failure and Post- breakage Strength of Hybrid Timber- Glass Beams, Slovak Society of Mechanics SAS,Bratysława,2012.

6. Dias V, Odenbreit $\mathrm{C}$, Hechler O, Scholzen $\mathrm{F}$, BenZineb $\mathrm{T}$. Development of a constitutive hyper elastic material law for numerical simulations of adhesive steel- glass connections using structural silicone, International Journal of Adhesion and Adhesives, 2014; 48:194-209.

7. Ungemann, E. Preckwinkel, Structural behavior of hybrid steel glass beams. TU Delft, MAJ, 2011, 485-495.

8. L.Blyberg, E.Serrano, B. Enquist, M.Sterley, Adhesives joints for timber/glass applications-part 1: mechanical properties in shear and tension.

9. J. Hamm, Development of timber-glass prefabricated structural elements. Lahti, 2001, 41- 46.

10. K.Kreher, Tragverhalten und Bemessung von Holtz-Glas-Verbuntragermunter Berucksichtigung der Eigenspannungeniumglas, P.Cruz, J.Pequeno, Timber-Glass composite beams: mechanical behavior and architectural solutions, Delft, 2008, 439-449.

11. L. Blyberg, M. Lang, L. Blyberg, M. Lang,E. Serrano, M. Silfverhielm, C. Stälhandske, Glass, timber and adhesive joints innovative load bearing building components, Constructon Building Materials, (2014)470-478.

12. L. Blyberg, E. Serrano, B. Enquist, M. Sterley, Adhesive joints for structural timber/glass applications: Experimental testing and evaluation methods, International Journal of Adhesion and Adhesives, (2012) 76-87.

13. J. Hulimka, M. Kozłowski, Mechanism of Failure and Postbreakage Strength of Hybrid Timber-Glass Beams, Slovak Society of Mechanics SAS, Bratysława, 2012. Archives of civil and Mechanical Engineering, 18 (2018) 956-964

14. M. Kozłowski, E. Serrano, B. Enquist, Experimental Investigation on Timber-Glass Composite I-Beams, Taylor \& Francis Group, London, 2014.

15. M. Kozłowski, M. Kadela, J. Hulimka, Numerical investigation of structural behaviour of timber-glass composite beams, Procedia Engineering, (2016).

16. P.Cruz, J.Pequeno, Timber-Glass composite beams: Mechanical behaviour and architectural solutions, Delft, 2008, 439-449.

\section{AUTHORS PROFILE}

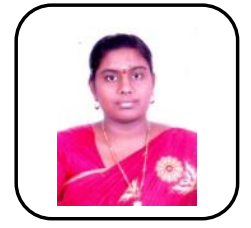

Mrs.S.Revathi, is Assistant Professor in Department of Civil Engineering. Her area of expertise is composite structures. She has published about 5 papers in reputed journals and also she has presented about 12 papers in national and international conferences in reputed institutions. She is a life member of ISTE.

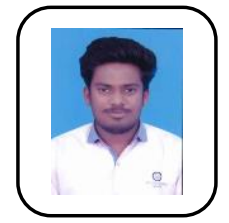

Mr.M.Washim Madhar, completed UG degree from Sri Vidya College of Engineering and Technology and now pursuing PG Structural Engineering in Mepco Schlenk Engineering College, Sivakasi. 